\title{
Preparation of Low-Protein Natural Rubber Latex: Effect of Polyethylene Glycol
}

\author{
G. Abhilash, ${ }^{1}$ S. Sabharwal, ${ }^{2}$ Abhinav Dubey, ${ }^{2}$ Jose Paul, $^{3}$ Honey John, ${ }^{4}$ Rani Joseph ${ }^{1}$ \\ ${ }^{1}$ Department of Polymer Science and Rubber Technology, Cochin University of Science and Technology, \\ Cochin 682022, Kerala, India \\ ${ }^{2}$ Radiation Technology Development Section, Bhabha Atomic Research Centre, Trombay, Mumbai 400085, \\ Maharashtra, India \\ ${ }^{3}$ Primus Gloves Private Limited, Kakkanadu, Cochin 682037, Kerala, India \\ ${ }^{4}$ Indian Institute of Space Science and Technology, Thiruvananthapuram 695022, Kerala, India
}

Received 26 March 2008; accepted 3 March 2009

DOI 10.1002/app.30491

Published online 15 June 2009 in Wiley InterScience (www.interscience.wiley.com).

\begin{abstract}
Low-protein content natural rubber latex was produced by using a nonionic surfactant-polyethylene glycol (PEG). Extractable protein content of natural rubber latex was found to decrease with PEG treatment and reduction increased with increase in the molecular weight of PEG. The low-protein latex samples were characterized by tensile testing, Fourier transform infrared and thermogravimetric analysis. The results have shown 35\% reduction
\end{abstract}

in the extractable protein content, without any compromise on the mechanical properties of the latex; however, thermal stability of low-protein latex was found to be reduced marginally with PEG treatment. 02009 Wiley Periodicals, Inc. J Appl Polym Sci 114: 806-810, 2009

Key words: aging; films; latices; mechanical properties; proteins

\section{INTRODUCTION}

The applicability of gloves and other latex products is restricted because of allergic problems associated with natural rubber latex. ${ }^{1,2}$ It has been reported that some of the proteins present in the latex are mainly responsible for the allergic reactions. ${ }^{3-11}$ Significant reduction in the allergic response of natural rubber latex can be achieved by the reduction in its protein content, however, out of the total proteins present in the latex or latex film only a fraction is extractable. ${ }^{12}$

Several techniques are available to reduce the protein content of the latex, such as leaching, autoclaving, chlorination, use of proteolytic enzymes, and use of nonionic surfactants. Leaching is effective only when we do that process for a few hours and so it is not commercially viable in reducing protein content to a greater level for production of gloves, catheters, etc. Steam autoclaving can affect physical properties unless precautionary measures are taken at the compounding stage. The use of chlorination may affect the strength of the gloves and it reduces the color of the gloves. Proteolytic enzymes are proteins and so we cannot rule out the possibility of them leading to a new allergy. ${ }^{13}$ Moreover, a long incubation time is needed for enzymatic deproteinisation. ${ }^{14}$ But the use of nonionic surfactant ${ }^{15,16}$ is a

Correspondence to: R. Joseph (rani@cusat.ac.in).

Journal of Applied Polymer Science, Vol. 114, 806-810 (2009)

(c) 2009 Wiley Periodicals, Inc. comparatively better method and it will not affect the mechanical properties to a greater extent. This article describes a method for protein reduction by using a nonionic surface active material and subsequent characterization of low-protein rubber latex.

\section{EXPERIMENTAL}

\section{Materials used}

Natural rubber latex of dry rubber content (DRC) $32.7 \%$ was procured from M/s Wynad resins, Kerala. Polyethylene glycol (PEG) was obtained from SD Fine Chemicals, Mumbai, India. Sodium chloride, potassium dihydrogen phosphate, hydrated disodium hydrogen phosphate, potassium chloride, sodium carbonate, sodium hydroxide, cupric sulfate pentahydrate, and sodium deoxycholate (DOC) were procured from E.Merck India, Mumbai. Follins reagent and trichloroacetic acid (TCA) were obtained from Merck Specialities, Mumbai, India. Sodium tartarate was obtained from Qualigens Fine chemicals and phosphotungstic acid (PTA) was obtained from Loba Chemie, Mumbai. Standard protein solution was albumin from chicken egg white grade V (A-5503) and it was procured from Sigma-Aldrich, USA.

\section{Preparation of low-protein latex by treating with PEG}

To the field latex was added $10 \%$ aqueous solution of PEG to get a concentration of $0.2 \%(w / w)$. It was 
TABLE I

Formulation for Compounding Latex to Produce Gloves

\begin{tabular}{lc}
\hline Constituents & Concentration $(\mathrm{phr})$ \\
\hline Latex & 100 \\
Sulfur & 1.1 \\
Zinc oxide & 0.35 \\
ZMBT & 0.2 \\
$\mathrm{ZDEC}$ & 0.85 \\
$\mathrm{TiO}_{2}$ & 0.25 \\
Wingstay L & 0.75 \\
$\mathrm{KOH}$ & 0.15 \\
\hline
\end{tabular}

allowed to mature for $24 \mathrm{~h}$ and then centrifuged at an rpm of 7129 in a centrifuging factory. After that it was casted on to a glass tray to prepare the film. The film was leached in hot water kept at a temperature of about $80^{\circ} \mathrm{C}$ for about $2 \mathrm{~min}$. A known weight of the sample was taken and protein test was done by modified lowry method as per ASTM D 5712 : 99. Different molecular weights of PEG were added to the latex and their effect on the reduction of protein was studied. After optimizing the molecular weight, concentrations of PEG were varied from $0.1 \%$ to $0.3 \%$ and their efficiency was studied by making gloves using the three latices.

\section{Determination of protein content}

A known weight of the test specimen was extracted with a dilute extraction buffer of ratio $1: 9$ (buffer : water). The $\mathrm{pH}$ of the buffer solution was adjusted to $7.4 \pm 0.2$. The test specimen was immersed in the extraction buffer solution. The quantity of the extraction solution was between 5 and $10 \mathrm{~mL}$ per $1 \mathrm{~g}$ of the glove material or the latex film. Extraction was done at $25 \pm 5^{\circ} \mathrm{C}$ for $120 \pm 5 \mathrm{~min}$. The test specimen was removed from the extraction solution and the remaining solution was centrifuged to $15 \mathrm{~min}$ at $1865 \mathrm{rpm}$. Then $4 \mathrm{~mL}$ each of the reagent blank, standard protein solution, and the specimen extract were transferred into a polypropylene tube. A duplicate specimen extract was also taken. A total of 0.4 $\mathrm{mL}$ sodium deoxycholate (DOC) was added, mixed well, and kept for $10 \mathrm{~min}$. A total of $0.8 \mathrm{~mL}$ of freshly prepared solution of 50 : 50 TCA and PTA was added and the protein was precipitated as acid precipitate. The contents were mixed well and allowed to stand for $30 \mathrm{~min}$. The acid precipitate was centrifuged at $6236 \mathrm{rpm}$ for $15 \mathrm{~min}$.

A total of $1.2 \mathrm{~mL}$ of $0.2 \mathrm{~N} \mathrm{NaOH}$ solution was added to each tube, including blank so as to redissolve the precipitated protein and shaken well so that the protein was completely redissolved to a clear solution. A total of $2.5 \mathrm{~mL}$ of reagent C (alkaline copper tartarate solution) and $\mathrm{C}^{\prime}$ (alkaline tartarate solution) were added, respectively, to the specimen extract and duplicate. The solution were mixed well
TABLE II

Properties of Modified Lattices

\begin{tabular}{lccc}
\hline \multicolumn{1}{c}{ Type of Latex } & $\begin{array}{c}\text { DRC } \\
(\%)\end{array}$ & $\begin{array}{c}\text { MST } \\
(\mathrm{s})\end{array}$ & $\begin{array}{c}\mathrm{NH}_{3} \\
\text { content (\%) }\end{array}$ \\
\hline Latex without PEG treatment & 60.1 & 960 & 0.3 \\
Latex treated with PEG 4000 & 60.05 & 960 & 0.25 \\
Latex treated with PEG 6000 & 60.05 & 960 & 0.25 \\
Latex treated with PEG 9000 & 60.05 & 970 & 0.25 \\
Latex treated with PEG 20000 & 60.05 & 1010 & 0.21 \\
\hline
\end{tabular}

and kept for $15 \mathrm{~min}$ at room temperature. A total of $0.3 \mathrm{~mL}$ of $50 \%$ follins reagent was added to each of them and thoroughly mixed immediately. Then both were kept for $30 \mathrm{~min}$ at room temperature.

The final assay mixture was transferred to a cuvette and the concentration of the standard solution $\mathrm{C}$ and $\mathrm{C}^{\prime}$ were measured.

$$
\text { Extractable protein content, E.P }=\frac{C \times V \times F}{S}
$$

where $C$ is the protein concentration of extract in $\mu \mathrm{g} / \mathrm{mL}, V$ the volume of extraction buffer in $\mathrm{mL}, F$ the dilution factor, and $S$ the surface area in $\mathrm{dm}^{2}$ of the NR specimen, i.e.

$$
\frac{\text { length }(\mathrm{mm}) \times \text { width }(\mathrm{mm}) \times 4}{10,000}
$$

\section{Characterization}

Characterization of the optimized samples was done by using Fourier transform infrared (FTIR) spectrometer (Bruker, Tensor 27) and Thermogravimetric Analyzer (Q50, TA Instruments).

\section{Production of gloves using treated latex}

Gloves were made using 0.1, 0.2, and 0.3\% PEG (molecular weight 20,000) containing latices. The latices were compounded using the formulation given below in Table I. Gloves were produced by first dipping the preheated former in compounded latices containing PEG for 40 seconds. All other parameters required to make gloves were kept constant as factory conditions.

TABLE III

Protein Content of Uncompounded Lattices

\begin{tabular}{lc}
\hline \multicolumn{1}{c}{ Latices used } & $\begin{array}{c}\text { Protein content } \\
\text { (microgram per gram) }\end{array}$ \\
\hline Latex without Surfactant & 49.14 \\
Latex with PEG(mol. wt 4000) & 47.29 \\
Latex with PEG(mol. wt 6000) & 38.89 \\
Latex with PEG(mol. wt 9000) & 35.02 \\
Latex with PEG(mol. wt 20,000) & 32.13 \\
\hline
\end{tabular}


TABLE IV

Properties of Latex Without Surfactant Treatment and Latices Treated With $0.1,0.2$, and $0.3 \%$ PEG

\begin{tabular}{|c|c|c|c|c|}
\hline Properties & $\begin{array}{c}\text { Latex Without } \\
\text { surfactant treatment }\end{array}$ & $0.1 \% \mathrm{PEG}$ & $0.2 \%$ PEG & $0.3 \% \mathrm{PEG}$ \\
\hline Total solid content (\%) & 61.4 & 64.6 & 64.65 & 64.66 \\
\hline Dry rubber content (\%) & 60.1 & 63.3 & 63.2 & 63.3 \\
\hline Ammonia content (\%) & 0.3 & 0.3 & 0.3 & 0.3 \\
\hline VFA number ${ }^{a}$ & 0.041 & 0.047 & 0.047 & 0.05 \\
\hline $\mathrm{KOH}$ number ${ }^{\mathrm{b}}$ & 0.5 & 0.5 & 0.5 & 0.5 \\
\hline MST (s) & 960 & 1000 & 1010 & 1030 \\
\hline
\end{tabular}

${ }^{a}$ VFA number (volatile fatty acid number) - the number of grams of potassium hydroxide equivalent to the anions present as salts of steam-volatile acids in a quantity of latex, which contains $100 \mathrm{~g}$ of the total solids.

${ }^{\mathrm{b}} \mathrm{KOH}$ number - the number of grams of potassium hydroxide equivalent to the anions present as ammonium salts in a quantity of latex which contains $100 \mathrm{~g}$ of total solids.

\section{Tensile properties}

Tensile properties were performed on Shimadzu autograph AG1 series as per ASTM D412 at a crosshead speed of $500 \mathrm{~mm} / \mathrm{m}$.

\section{RESULTS AND DISCUSSION}

The properties of the modified latices like DRC, mechanical stability time (MST), and ammonia content are given in Table II. It is clear from the MST values that the latex is stabilized by the addition of PEG and it is higher for the latex treated with PEG having molecular weight 20,000. Table III shows the protein content of latex without surfactants and latices treated with different molecular weights of PEG. Proteins get adsorbed on PEG. It is clear from Table III that enhanced reduction in protein content is observed when PEG of higher molecular weight is treated with latex. This may be due to the increase in hydrogen bonding owing to the increase in oxygen atoms in the repeating units of PEG with higher molecular weights. The PEG-protein moiety can be removed from latex by centrifugation. Commercial viability cannot be achieved if we increase the molecular weight beyond 20,000 because of the high cost of PEG for its higher molecular weights. Therefore, because of the higher protein reducing capacity and mechanical stabilization, PEG having molecular weight 20,000 was taken for further study.

Table IV shows the properties of centrifuged latex without PEG treatment and latices treated with 0.1 , 0.2 , and $0.3 \%$ PEG having molecular weight 20,000. It can be seen that the latex properties are more or less uniform for latices with and without PEG. Table $\mathrm{V}$ shows the extractable protein content of gloves prepared (as per formulation given in Table I) from latex concentrated with $0.1,0.2$, and $0.3 \%$ PEG (molecular weight 20,000) and that of centrifuged latex without PEG. It is clear from the table that $0.2 \%$ PEG effectively reduces the protein content compared with glove produced from centrifuged latex without PEG treatment, whereas 0.3\% PEG shows only a very marginal decrease. Moreover, the cost will be increased if we use $0.3 \%$ PEG.

Required chloroform number is between 3 and 4 . (It is an arbitrary number that is assigned to the latex on the basis of appearance. Four stages of prevulcanisation are usually distinguished by this test and are assigned as follows:

Chloroform number 1-coagulum is a tacky mass, breaking in a stringy manner when stretched.

Chloroform number 2-the coagulum is a weak lump, which breaks short when stretched.

Chloroform number 3-the coagulum has the form of a nontacky agglomerate.

Chloroform number 4-the coagulum has the form of small dry crumbs.)

Latex with $0.2 \%$ PEG attained the chloroform number within $48 \mathrm{~h}$. But it takes $96 \mathrm{~h}$ in the case of latex with $0.3 \%$ PEG. Therefore, for further studies, latex prepared with $0.2 \%$ PEG (molecular weight $20,000)$ is selected.

TABLE V

Protein Content of Gloves Prepared from Latices of Different Percentages of PEG (Molecular Weight 20,000) and from Latex Without Surfactant Treatment

\begin{tabular}{lc}
\hline \multicolumn{1}{c}{ Latex used } & Proteins $\left(\mu \mathrm{g} / \mathrm{dm}^{2}\right)$ \\
\hline $0.1 \%$ PEG & 57.05 \\
$0.2 \%$ PEG & 47.93 \\
0.3\% PEG & 47.96 \\
Centrifuged latex without PEG & 85.01 \\
\hline
\end{tabular}


TABLE VI

Tensile Properties of Gloves Before and After Aging Prepared by Treating Latex With 0.2\%PEG

\begin{tabular}{cccccccc}
\hline & Before aging & & & \multicolumn{3}{c}{ After aging } \\
\cline { 1 - 2 } $\begin{array}{c}\text { Stress at 500\% } \\
\text { elongation (MPa) }\end{array}$ & $\begin{array}{c}\text { Elongation } \\
\text { at break (\%) }\end{array}$ & $\begin{array}{c}\text { Tensile } \\
\text { strength (MPa) }\end{array}$ & & $\begin{array}{c}\text { Stress at 500\% } \\
\text { elongation (MPa) }\end{array}$ & & $\begin{array}{c}\text { Elongation } \\
\text { at break (\%) }\end{array}$ & $\begin{array}{c}\text { Tensile } \\
\text { strength (MPa) }\end{array}$ \\
\hline 2.24 & 940 & 24.5 & & 2.7 & 910 & 2.6 \\
2.27 & 940 & 24.9 & & 2.65 & 910 & 2.6 \\
2.27 & 940 & 24.9 & & 2.65 & 910 & 22.4 \\
\hline
\end{tabular}

TABLE VII

Specifications of Mechanical Properties of Surgical and Examination Gloves

\begin{tabular}{|c|c|c|c|c|c|}
\hline \multirow[b]{2}{*}{ Type of glove } & \multicolumn{3}{|c|}{ Before aging } & \multicolumn{2}{|c|}{ After aging } \\
\hline & $\begin{array}{c}\text { Stress at } 500 \% \\
\text { elongation }(\mathrm{MPa})\end{array}$ & $\begin{array}{l}\text { Elongation } \\
\text { at break (\%) }\end{array}$ & $\begin{array}{c}\text { Tensile } \\
\text { strength }(\mathrm{MPa})\end{array}$ & $\begin{array}{l}\text { Elongation } \\
\text { at break (\%) }\end{array}$ & $\begin{array}{c}\text { Tensile } \\
\text { strength (MPa) }\end{array}$ \\
\hline Surgical & $<5.5$ & $\geq 750$ & $\geq 24.0$ & $\geq 560$ & $\geq 18$ \\
\hline Examination (type I) & $2.8-5.5$ & $\geq 650$ & $\geq 18$ & $\geq 500$ & $\geq 14$ \\
\hline Examination (type II) & $<2.8$ & $\geq 650$ & $\geq 14$ & $\geq 500$ & $\geq 14$ \\
\hline
\end{tabular}

TABLE VIII

Tensile Properties of Commercial Gloves

\begin{tabular}{cccccc}
\hline & \multicolumn{3}{c}{ Before aging } & & \multicolumn{2}{c}{ After aging } \\
\cline { 1 - 2 } \cline { 5 - 6 } $\begin{array}{c}\text { Stress at 500\% } \\
\text { elongation }(\mathrm{MPa})\end{array}$ & $\begin{array}{c}\text { Elongation } \\
\text { at break }(\%)\end{array}$ & $\begin{array}{c}\text { Tensile } \\
\text { strength }(\mathrm{MPa})\end{array}$ & & $\begin{array}{c}\text { Elongation } \\
\text { at break }(\%)\end{array}$ & $\begin{array}{c}\text { Tensile } \\
\text { strength (MPa) }\end{array}$ \\
\hline 2.34 & 923 & 25.52 & & 812 & 22.0 \\
2.97 & 925 & 25.74 & & 864 & 21.44 \\
3.1 & 920 & 26.01 & & 849 & 22.2 \\
\hline
\end{tabular}

Tensile strength of the gloves prepared by using $0.2 \%$ PEG before and after aging is found out by cutting dumbbell shaped samples from the gloves and it is found that it meets the specification requirements of both examination (type II) and surgical gloves. The tensile properties before aging and after

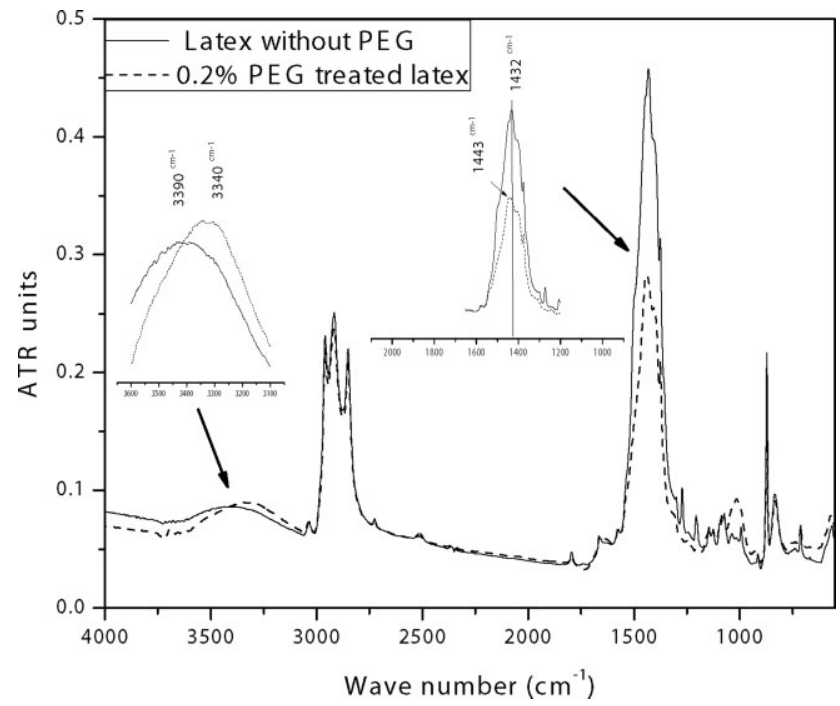

Figure 1 Infrared spectra of latex without PEG treatment and latex with $0.2 \%$ PEG treatment. aging (at $100^{\circ} \mathrm{C}$ for $22 \mathrm{~h}$ in a hot air oven) are given in Table VI. Specifications of surgical and examination gloves are given in Table VII as per ASTM D 3577 and ASTM D 3578, respectively. Tensile

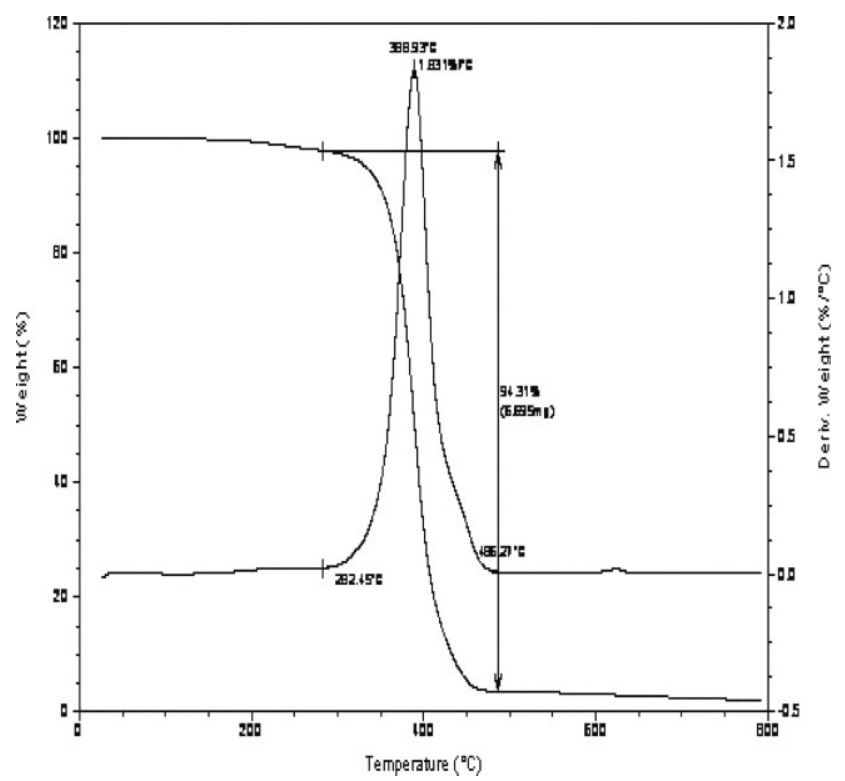

Figure 2 TGA curve of centrifuged latex without PEG treatment. 


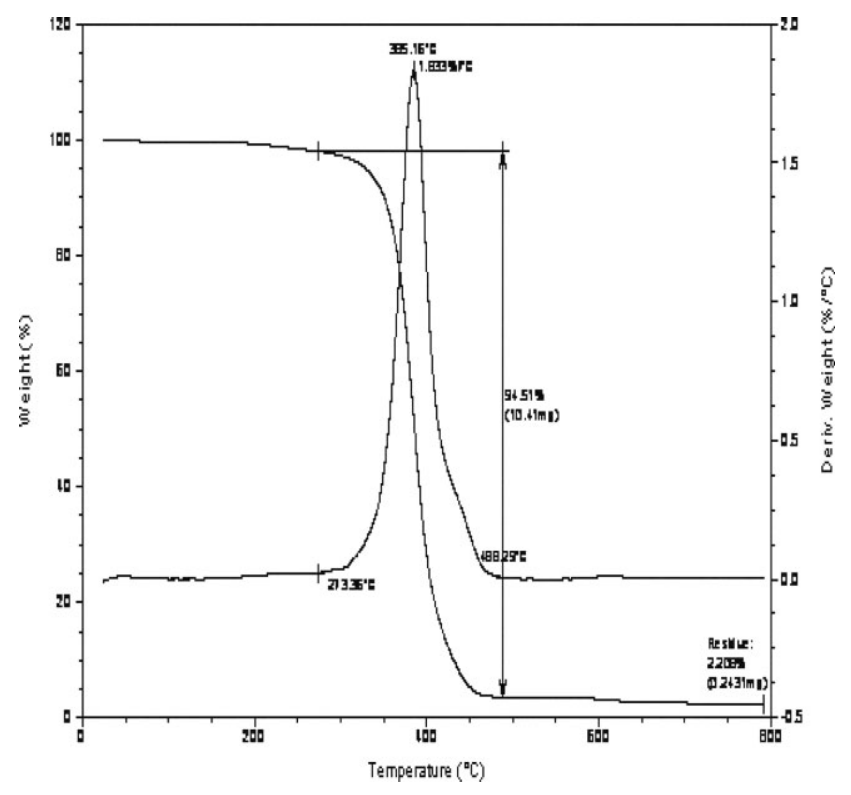

Figure 3 TGA curve of $0.2 \%$ PEG-treated latex.

properties of commercial gloves are given in Table VIII. FTIR spectra of the aforesaid low-protein latex (compounded) film and that of compounded latex film without PEG treatment were shown in Figure 1. For the compounded latex film without PEG, a peak at $3390 \mathrm{~cm}^{-1}$ is observed, which shifted to 3340 $\mathrm{cm}^{-1}$ in the case of $0.2 \%$ PEG-treated latex. The lower frequency shift is due to the reduction in peptide linkage, which originates from the protein present in the latex. The peak at $1432 \mathrm{~cm}^{-1}$ corresponding to the $-\mathrm{NH}$ deformation (in latex without PEG treatment) is shifted to $1443 \mathrm{~cm}^{-1}$ in the case of $0.2 \%$ PEG-treated latex and also the intensity of the peak is reduced considerably indicating the reduction in free $-\mathrm{NH}$ concentration, which, in turn, indicates the reduction in protein content. The peak present at $1015 \mathrm{~cm}^{-1}$ in PEG-treated latex shows the presence of ether linkage due to the presence of traces of PEG in the latex.

Figures 2 and 3 shows the TGA thermogram of centrifuged latex film without PEG and PEG-treated latex film respectively. In the case of latex without PEG treatment, the degradation starts at $282.4^{\circ} \mathrm{C}$ but it is shifted to $273.4^{\circ} \mathrm{C}$ in the case of PEG-treated latex. Peak degradation temperature of latex film without PEG treatment is $388.9^{\circ} \mathrm{C}$ with rate $1.83 \% /{ }^{\circ} \mathrm{C}$ and that of PEG-treated latex film is $385.2^{\circ} \mathrm{C}$ with rate $1.83 \% /{ }^{\circ} \mathrm{C}$. Hence, the addition of PEG slightly reduces the thermal stability of the latex film.

\section{CONCLUSIONS}

Low-protein latex was successfully prepared with PEG. About 35\% reduction in the extractable protein content of natural rubber latex was observed when PEG was incorporated. The reduction in extractable protein content was found to be increased with increase in PEG (molecular weight 20,000) up to $0.2 \%$, but did not show significant increase on further increase in PEG concentration. The FTIR spectra also confirm significant reduction in the protein content after PEG treatment. The mechanical properties of the gloves produced from low-protein latex were found to be similar to that of commercial latex gloves.

\section{References}

1. Gershwin, M. E. Clin Rev Allergy 1993, 11, 293.

2. Taylor, J.; Leow, Y. H. Rub Chem Technol 2000, 73, 420.

3. Slater, J. E. N Engl J Med 1989, 320, 1126.

4. Leynadier, F. C.; Pecquet, C. J Dry Anasthesia 1989, 44, 547.

5. Turjannama, K.; Rasanen, L.; Lelito, M.; Makinan-Kiljunen, S.; Reunala, T. Allergy 1989, 44, 181.

6. Arreguin, B.; Lara, P.; Rodriquez, R. Electrophoresis 1988, 9, 323.

7. Hasma, H. J Nat Rub Res 1992, 7, 102.

8. Slater, J. E.; Chhabra, S. K. J Allergy Clin Immunol 1992, 89, 673.

9. Lee, H. I.; Brockacrt, W. F.; Raikhel, N. V. J Biol Chem 1991, 256, 15944.

10. Jekel, P. A.; Hartmann, B. H.; Beintema, J. Eur J Biochem 1991, 200, 123.

11. Levy, D. A. Proceedings of the International Conference on Latex protein Allergy: The Present Position; Amsterdam, 1993, 33.

12. Hasma, H. Proceedings of the IRTC'93, Workshop on Latex Proteins; Rubber Research Institute of Malaysia: Kuala Lumpur, 1994, 27.

13. Bez, W. Proceedings of the Second International Seminar on RVNRL; Kuala Lumpur, 1996, 121.

14. Warunee, K.; Takayuki, S.; Seiichi, K.; Kei, T.; Yasuyuki, S.; Jitladda, T. S.; Yoshinobu, I. J Appl Polym Sci 2004, 93, 555.

15. Ichikawa, N.; Hwee, E. A.; Tanaka, Y. Proceedings of the International Rubber Technology Conference; Kuala Lumpur, 1993, 101.

16. Schloman, W. W. Trends in New Crops and New Uses; ASHS press: Alexandria, 2002, p 245. 